\title{
Differential activation of Fas (CD95) mediated apoptosis by apple procyanidins in human colon cancer cells SW480 and their derived metastatic cells SW620
}

\author{
María Elena Maldonado-Celis, PhD ${ }^{1-3}$, Souad Bousserouel, PhD ${ }^{1,2}$, \\ Francine Gossé, Eng ${ }^{1,2}$, Annelise Lobstein, PhD4, Francis Raul, PhD ${ }^{1,2}$
}

\section{SUMMARY}

Introduction: We investigated the effects of apple procyanidins (Pcy), oligomers of catechins and epicatechins on Fas receptor expression and function in human colon adenocarcinoma cells (SW480) and in their derived metastatic cells (SW620).

Methods: Pcy were characterized by reverse-phase HPLC. Cell death, Fas proteins, DNA fragmentation, and mitochondrial membrane potential were analyzed by flow cytometry. Fas mRNA was analyzed by RT-PCR in real time.

Results: Pcy up-regulated the expression of the Fas receptor at the cell surface of both cell lines but activated Fas gene transcription only in SW620 cells. In SW480 cells, Pcy combined with Fas agonist CH-11 enhanced Fas-mediated apoptosis involving the loss of mitochondrial membrane potential and DNA fragmentation, which were abrogated by the antagonist antibody of Fas receptor, the anti-Fas ZB4. On the contrary, in SW620 cells, CH-11 was not able to enhance Pcy-triggered apoptosis indicating that Fas receptor-mediated apoptosis was not activated in these cells despite an up-regulation of Fas receptor gene expression. However, it was observed in SW620 cells that Pcy activated the Fas receptor-mediated apoptotic pathway after a specific blockage of TRAIL-death DR4/DR5 receptors.

Conclusions: The present data showed that Pcy were able to activate the Fas receptor apoptotic pathway in SW480 cells and favored a cross-talk between TRAIL and Fas receptors in SW620 cells because specific blocking of TRAIL death receptors favored activation of the Fas receptor-mediated apoptosis. These important data may allow the emergence of new therapeutic protocols targeting death receptors against resistant metastatic cells.

Keywords: Apoptosis; Colorectal cancer; Flavonoids; Procyanidins; Fas; TRAIL.

Colomb Med. 2011; 42: 166-76

Activación diferencial de la apoptosis vía Fas (CD95) por procianidinas de manzana en células humanas de cáncer de colon y sus derivadas metastásicas

\section{RESUMEN}

Introducción: Se estudiaron los efectos de procianidinas (Pcy) de manzana, oligómeros de catequinas y epicatequinas en la expresión y función del receptor Fas en células humanas de cáncer de colon (SW480) y sus derivadas metastásicas (SW620).

Métodos: Las Pcy se caracterizaron por cromatografía líquida de alta presión (HPLC) en fase-reversa. Se analizaron por citometría de flujo la muerte celular, la proteína Fas, la fragmentación del ADN y el potencial de la membrana mitocondrial. Se analizaron los transcriptos de Fas por RT-PCR en tiempo real.

1. Institut pour la Recherche des Cancers de l'appareil digestif (IRCAD), Laboratory of Nutritional Cancer Prevention, Strasbourg, France. e-mail: mariaele@quimbaya.udea.edu.co

2. Professor, University of Strasbourg, Unit of Pathophysiology and Translational Research, Faculty of Medicine, Strasbourg, France. e-mail: sb_souad@yahoo.fr francine.gosse@ircad.u-strasbg.fr francis.raul@ircad.u-strasbg.fr

3. Professor, Research Group on Food and Human Nutrition, School of Nutrition and Dietetics, Universidad de Antioquia, Medellín, Colombia.

4. Professor, Centre Nationa pour la Recherche Scientifique (CNRS UMR7081), University of Strasbourg, Faculty of Pharmacy, Illkirch, France. e-mail: annelise.lobstein@pharma.u-strasbg.fr

Received for publication February 2, 2010 Accepted for publication August 26, 2010 
Resultados: Las Pcy aumentaron la expresión del receptor Fas en la superficie celular de ambas líneas celulares pero la transcripción del gen Fas fue activado transcripcionalmente sólo en las células SW620. En las células SW480, las Pcy combinadas con el agonista de Fas $\mathrm{CH}-11$ potenció la apoptosis mediada por Fas involucrando la pérdida del potencial mitocondrial de membrana y la fragmentación del ADN los cuales fueron evadidos por el anticuerpo antagonista del receptor Fas anti-ZB4. Por el contrario, en las células SW620, CH-11 no fue capaz de potenciar la apoptosis activada por Pcy indicando que la apoptosis mediada por el receptor Fas no fue activada en estas células a pesar del aumento en la expresión de Fas por regulación a nivel transcripcional. Sin embargo, se observó en las células SW620 que las Pcy activaron la vía apoptótica mediada por el receptor Fas después de un bloqueo específico de los receptores de muerte TRAIL DR4/DR5.

Conclusiones: Estos datos muestran que las Pcy fueron capaces de activar la apoptosis a través del receptor Fas en las células SW480 y favorecieron una intercomunicación entre los receptores TRAIL y Fas en las células SW620 debido a que el bloqueo específico de los receptores de muerte TRAIL favoreció la activación de la apoptosis mediada por el receptor Fas. Estos datos podrían permitir el surgimiento de nuevos protocolos terapéuticos dirigidos contra receptores de muerte en células metastásicas resistentes.

Palabras clave: Apoptosis; Cáncer colorectal; Flavonoides; Procianidinas; Fas; TRAIL.

\section{Colomb Med. 2011; 42: 166-76}

Over the past few years, it has been shown that phytochemicals present in the human diet can prevent the occurrence of degenerative diseases such as cancer ${ }^{1}$. Apples are a rich source of polyphenol constituents, especially of flavonoids distributed in the peel, core, and pulp. Flavonoids present in apples are divided into different classes: flavonols like quercetin conjugates (3-galactoside, 3-glucoside, and 3-rhamnoside), flavan3-ols derivatives including oligomers formed by catechin and epicatechin units, and the procyanidins (Pcy) ${ }^{2}$.

Pcy have recently gained interest because of potential health promoting effects by acting as antioxidant, anticarcinogen, cardio-preventive, antimicrobial, antiviral, and neuro-protective agents ${ }^{2}$. We have recently reported that apple Pcy inhibit the growth of human metastatic colon adenocarcinoma-derived SW620 cells through the inhibition of protein kinase $\mathrm{C}$ activity, down-regulation of polyamine biosynthesis and activation of polyamine catabolism, and through Pcytriggered apoptosis involving TRAIL receptor-mediated pathway $^{3-5}$. It was also reported that apple Pcy can inhibit the promotion/progression phases of colon carcinogenesis in rats $^{3}$. However, the cellular and molecular mechanisms by which Pcy induce apoptosis in cancer cells are not well understood. Previously, we reported that TRAIL-DR4/DR5 blocking antibodies increased Pcy-triggered apoptosis in SW620 cells ${ }^{4}$. These data suggested the activation of an alternative death pathway. In the present report, we investigated on the possible implication of the Fas pathway.

Fas (Apo-1/CD95) is a member of the tumour necrosis factor (TNF) receptor super family activated by Fas-ligand (FasL) or certain agonist anti-Fas antibodies ${ }^{6}$ resulting from the activation of an apoptotic process in sensitive cells. The Fas system is one of the death-pathways activated in tumour cells by cytotoxic T lymphocyte cells in the human body. The signals of Fas ligand (FasL) or agonist antibodies are transduced by intracellular death domains that interact with adapter molecules, which are conserved among the TNF receptor super family (TRAIL-DR4/DR5, TNFR1). The adapter molecule Fas-associated death domain (FADD) binds directly to the death domains of the TNF receptor super family to transduce the apoptotic signal leading to the activation of caspase- 8 and, subsequently, to the downstream activation of effector caspases such as caspase-3. Activation of the Fas pathway may also induce a mitochondria-dependent apoptotic pathway and, depending on the cell type, either one or both signaling pathways may be activated ${ }^{6}$.

Most cancer cells, unlike normal cells, are resistant to Fas-mediated apoptosis, allowing immune escape and cell growth of a selective population of malignant cells that may consequently facilitate metastatic spread ${ }^{7,8}$. The loss of sensitivity to Fas-mediated apoptosis may play an important role in the progression of malignancy. This is supported by the observation that tumour cells displaying resistance to chemotherapeutic agents may concomitantly exhibit resistance to functional Fas expression ${ }^{9}$. In the present report, we investigated the effects of apple Pcy on Fas receptor expression and function in human colon adenocarcinoma SW480 cells and in their Fas-resistance derived metastatic SW620 cells. 


\section{MATERIALS AND METHODS}

Isolation and characterization of apple procyanidins. Polyphenols were purified as described in Maldonado-Celis et al. ${ }^{5}$ In brief, cider apples (Malus domestica, Antoinette variety) were reduced into a homogeneous powder extracted by water:ethanol:acetic acid (975:1000:25). After filtration, evaporation under vacuum and freeze drying, the crude extract was dissolved in $2.5 \%$ acetic acid and separated by preparative HPLC (Lichrospher RP 18, $12 \mu \mathrm{m}$, Merck, Darmstadt, Germany) to remove sugars and other nonphenolic polar compounds. Polyphenols were eluted with acetonitrile:water:acetic acid (300:700:25). Fractions containing polyphenols were evaporated and freeze-dried. The polyphenols were fractionated on a Fractogel column by a method adapted from Souquet $e t$ al. ${ }^{10} \mathrm{Pcy}$ were characterized and quantified by thiolysis coupled with reverse-phase HPLC. On a weight basis, the Pcy-fraction contained $78 \%$ Pcy, consisting of $95 \%$ (-)-epicatechin and 4\% (+)-catechin. The mean degree of polymerization was close to seven. The Pcy fraction was almost totally devoid of monomeric flavonoids and other phenols $(<2 \%)$. Pcy was diluted in dimethylsulfoxide (DMSO) and used at $80 \mu \mathrm{g} / \mathrm{ml}$ final concentration.

Cell culture and treatments. SW480 and SW620 cells were obtained from the European Collection of Animal Cell Culture (ECACC, Salisbury, UK). They were cultured in $75 \mathrm{~cm}^{2}$ Falcon flasks in Dulbecco's modified Eagle's medium containing $25 \mathrm{mM}$ glucose and $2 \mathrm{mM}$ L-glutamine, $10 \%$ heat-inactivated $\left(56^{\circ} \mathrm{C}\right)$ horse serum, $100 \mathrm{U} / \mathrm{ml}$ penicillin, $100 \mu \mathrm{g} / \mathrm{ml}$ streptomycin, and 1\% non-essential amino acids (Invitrogen Corp., Cergy Pontoise, France). Incubations were carried out at $37^{\circ} \mathrm{C}$ in a humidified atmosphere with $5 \% \mathrm{CO}_{2}$. The culture medium was replaced every $48 \mathrm{~h}$. For all experiments, horse serum was reduced to $3 \%$, and the medium was supplemented with $10 \mathrm{mg} / \mathrm{ml}$ insulin, 5 $\mathrm{mg} / \mathrm{ml}$ transferring, and $5 \mathrm{ng} / \mathrm{ml}$ selenium and (ITSdefined medium; Gibco, Invitrogen, Cergy-Pontoise, France). Cells were exposed to different compounds 24 $\mathrm{h}$ after seeding and incubated for 24 or $48 \mathrm{~h}$. DMSO final concentration in culture medium was $0.1 \%$ for control and treated cells. Stock solution of human Fasactivating monoclonal antibody (clone $\mathrm{CH}-11$; MBL, Nagoya, Japan) was tested at $50 \mathrm{ng} / \mathrm{ml}$. The human Fas- blocking antibody (clone ZB4; MBL, Nagoya, Japan) was added at $1 \mathrm{mg} / \mathrm{ml} 1 \mathrm{~h}$ before treatment with Pcy. For experiments with DR4/DR5 blocking antibodies, cells were pre-treated with human blocking anti-DR4 and anti-DR5 (250 ng/ml) (Alexis Biochemicals, Switzerland) for $24 \mathrm{~h}$ before Pcy treatment.

Detection of cell surface expression of Fas receptor (CD95). Cells were treated with Pcy $(80 \mu \mathrm{g} / \mathrm{ml})$ for $48 \mathrm{~h}$ and harvested by trypsinization. Cells pellets were washed with PBS and incubated for $30 \mathrm{~min}$ at $4^{\circ} \mathrm{C}$ in darkness with FITC-conjugated mouse anti-humanCD95 (IgG1k, clone DX2, 1:50) (BD Pharmingen, San José CA, USA) or FITC-conjugated mouse IgG1 monoclonal isotype control antibody (BD Bioscence, Belgium) for $30 \mathrm{~min}$ at $4{ }^{\circ} \mathrm{C}$ in the dark. After washing with PBS, cells were re-suspended in PBS, and the fluorescence of 10,000 events per sample was analyzed with a FACScan flow cytometer and CellQuest Software (BD Biosciences, Belgium).

Total RNA extraction and RT-PCR detection of Fas (CD95) $\boldsymbol{m} \boldsymbol{R} N \boldsymbol{A}$ transcripts. To know whether cell surface expression of Fas at the surface level was associated with levels of Fas RNA, the expression of Fas mRNA was quantified by real time RT-PCR and data were analyzed by relative quantification method ${ }^{11}$. Relative quantification describes the change in expression of the target gene (Fas) relative to untreated cells (control group) under same conditions for detection of cell surface expression of Fas. Total RNA from untreated and treated cells with Pcy was extracted by using an RNeasy mini kit (QIAGEN, VWR, Denmark) following manufacturer instructions. RNA was reversed transcribed by using the High-Capacity cDNA Archive Kit (Applied Biosystems, Foster City CA, USA). TaqMan Gene Expression assays were used to measure transcription levels of the selected genes (Fas receptor, Hs00236330 m1; Applied Biosystems). Beta actin was applied as an endogenous control (cat no Hs99999903 m1; Applied Biosystems). Real time RT-PCR was performed by using TaqMan Universal PCR master mix (Applied Biosystems) and ABI Prism 7500 Sequence Detection System (Applied Biosystems Sequence detector) in triplicate wells. Data were analyzed by a comparative threshold cycle $\left(\mathrm{C}_{\mathrm{T}}\right)$ method and statistical analysis was performed as described by Livak and Schmittgen ${ }^{11}$.

Cell death analysis by flow cytometry. We used 
propidium iodide staining to measure the percentage of cell population in the SubG0/G1 region, which exhibits DNA content lower than $2 \mathrm{n}$ caused characteristics of cells dying exhibiting DNA degradation. Thus, this approach allows determining the amount of dead or dying cells in a population but gives no information on the cell death process such as apoptosis ${ }^{12}$. SW480 and SW620 cells were seeded in culture dishes and harvested by trypsinization at 24 and $48 \mathrm{~h}$ after treatment with DMSO 0.1\% (control), Pcy $(80 \mu \mathrm{g} / \mathrm{ml}$ ), anti-Fas agonist CH-11, and blocking antibodies: anti-Fas ZB4, antiDR4, anti-DR5. Cells were centrifuged and fixed in 1 $\mathrm{ml}$ methanol:PBS $(9: 1, \mathrm{v} / \mathrm{v})$ at $-20^{\circ} \mathrm{C}$ for at least $30 \mathrm{~min}$, washed twice in phosphate buffer saline (PBS) and resuspended in $200 \mathrm{ml}$ PBS containing $0.25 \mathrm{mg} / \mathrm{ml}$ RNAse A and $0.1 \mathrm{mg} / \mathrm{ml}$ propidium iodide (PI) (SigmaAldrich, Munich, Germany), incubated in the dark at $37^{\circ} \mathrm{C}$ for $30 \mathrm{~min}$. The fluorescence of 10,000 cells was analyzed by flow cytometry and CellQuest software (FACScan, BD Biosciences, Erembodegem, Belgium).

Determination of apoptosis by terminal deoxynucleotide transferase (TdT) dUTP-biotin nick-end labeling (TUNEL) assay ${ }^{13}$. Cell DNA fragmentation was achieved via the TUNEL assay; the Mebstain apoptosis kit(MBL, Nagoya, Japan) was used following the manufacturer's instructions. Briefly, cells were washed with PBS ( $2 \%$ BSA) two times and fixed with $4 \%$ paraformaldehyde for $30 \mathrm{~min}$ at $4^{\circ} \mathrm{C}$. Cells were permeabilized by adding $200 \mathrm{ml}$ of $0.5 \%$ Tween- 20 with $0.2 \%$ BSA to the cell pellet. The TdT reaction was carried out in the presence of the FITC-dUTP reagent. For positive control, $\mathrm{H}_{2} \mathrm{O}_{2}(1.1 \%, \mathrm{v} / \mathrm{v})$ was added to the cell culture medium $30 \mathrm{~min}$ before trypsinization. Data from 10,000 events per sample were collected and analyzed by using a FACScan flow cytometer (FACScan, BD Biosciences, Erembodegem, Belgium).

Mitochondrial membrane permeability changes. Changes in mitochondrial membrane permeability were assessed by using the MitoProbe ${ }^{\mathrm{TM}} \mathrm{DiOC}_{2}(3)$ assay kit (Invitrogen Corp., France) as described previously ${ }^{5}$. Cells were cultured with Pcy and harvested by trypsinization at $48 \mathrm{~h}$. After trypsinization, cells were stained with $\mathrm{DiOC}_{2}(3)$ or for positive control with a mitochondrial membrane-potential disrupter, the carbonyl cyanide 3 -chlorophenylhydrazone (CCCP) at $50 \mu \mathrm{M}$ at $37^{\circ} \mathrm{C}$ for $30 \mathrm{~min}$ in darkness. Cells were washed and re-suspended in PBS to analyze 10,000 events by flow cytometry with excitation at $488 \mathrm{~nm}$ and green (FL-1: $515 \mathrm{~nm})$ or red (FL-3, (600 nm) emission filters according to manufacturer's instructions. This method allows quantifying cells with depolarized mitochondrial membrane by flow cytometry analysis using CellQuest Software (FACScan, BD Biosciences, Belgium).

Ethics. All the experiments were conducted adhering to institutional guidelines from the French Ethics Committee (authorization $N^{\circ} \mathrm{A} 67-480$, French Ministry of Agriculture).

Statistical analysis. All data were presented as mean \pm standard error (SE) from three independent experiments. Significant differences between control and treated groups were evaluated by one-way ANOVA analysis. Student's t test or Tukey's multiple comparison post-test was used to determine statistical differences between the data at the level of $p<0.05$. For the quantitative RT-PCR data, a paired t-test was used to evaluate differences between treatments at significance level of $p<0.0001$. Statistical analyses were performed by using GraphPad Prism version 4.0, 2003 (GraphPad Software, San Diego CA, USA).

\section{RESULTS}

Effect of Pcy on cell surface and $m R N A$ expression of Fas receptor in SW480 and SW620 cells. We measured the effect of Pcy on the cell surface expression of the Fas receptor by flow cytometry using a specific anti human-CD95-FITC antibody, by indicating the percentage of positive cells expressing Fas when fluorescence shift to the right was indicative of an increase of cells expressing Fas receptor at their cell surface (Figure 1A). The mean fluorescence intensity (MFI) was also determined by flow cytometry (Figure 1B), a numerical data was used as an indicator of antigen expression level per cell. As shown in Figure $1 \mathrm{~A}$ and $1 \mathrm{~B}$, the Fas receptor was already expressed at the surface of untreated SW480 cells, and Pcy-treatment caused a 3-fold increase of Fas receptor expression with respect to the control group. On the contrary, under basal conditions, only a very low percent of SW620 cells expressed the Fas receptor at their surface (3\%). After Pcy treatment, a huge increase $(>65 \%)$ in the amount of SW620 cells expressing the Fas receptor was observed, this corresponded to a 13-fold increased 

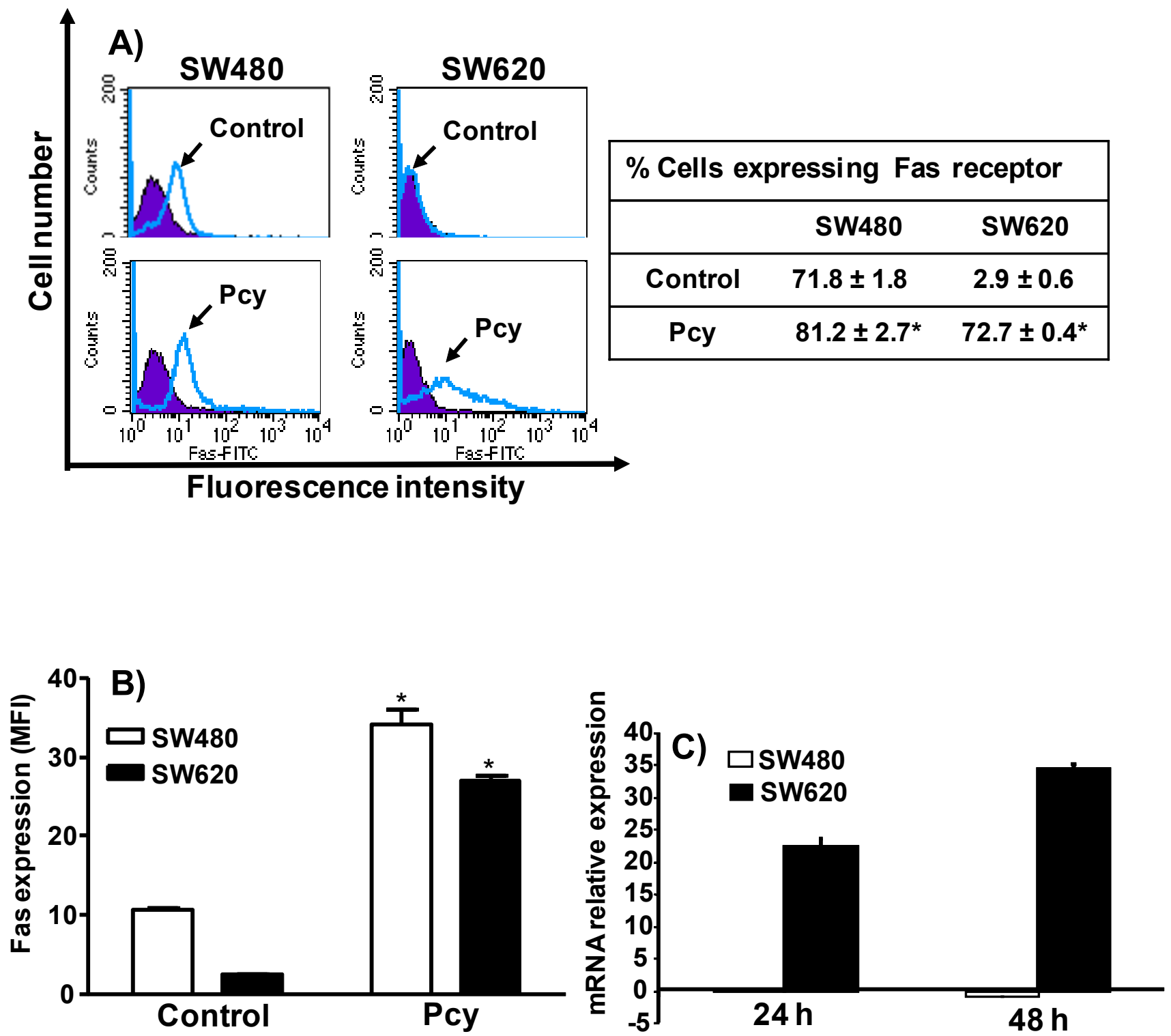

Figure 1. Fas expression of Pcy-treated SW480 and SW620 cells. Treatments were performed with Pcy or DMSO (control) for $48 \mathrm{~h}$. Percentage of cells expressing Fas-receptor (A) and mean fluorescence intensity (B) were analyzed by flow cytometry after staining with anti-CD95-FITC (open curve) or the respective isotype control (filled curve). (C) Fas mRNA expression levels were analyzed by RT-PCR, as described in the Materials and methods. (A), (B), and (C) are representative independent experiments $(n=3)$ for each cell line, data are the mean value \pm SE. In (A) and (B) comparisons were performed between control and Pcy-treated cells via one-way ANOVA: ${ }^{*} p<0.05$; in (C) by paired t-test: $p<0.001$.

expression of Fas receptor per cell when compared to untreated controls (Figure 1B).

In Figure 1C, the histograms represent the fold increased mRNA expression of Pcy-treated cells over non-treated cells analyzed by real time RT-PCR. Pcy treatment of SW620 cells caused a 22-fold (after $24 \mathrm{~h}$ ) and 35-fold (after $48 \mathrm{~h}$ ) increase of the Fas receptor transcripts, as measured by real time RT-PCR when compared to untreated cells (Figure 1C). In contrast, Pcy treatment did not change the level of Fas gene expression in SW480 cells. These data indicate that Pcy up-regulated the Fas receptor at a transcriptional level 
in SW620 cells; whereas, in the SW480 cell the Pcy regulated Fas receptor was expressed at a posttranscriptional level.

Effect of combined treatment with Pcy and agonist anti-Fas $\mathbf{C H}-11$ on cell death. SW 480 cells are known to be FasL-sensitive, while their derived metastatic SW620 cells are FasL-resistant ${ }^{7}$. As shown in Figure 2A, Pcy in combination with the Fas agonist $\mathrm{CH}-11$ increased by two-fold the amount of hypodiploid SW480 cells (Sub G0/G1 region) when compared to cells treated with Pcy used as a single drug. In contrast, in SW620 cells, Pcy in combination with $\mathrm{CH}-11$ did not affect the percentage of dead or dying cells.

We used the TUNEL method to detect the percentage of SW480 and SW620 cells with single DNA strand breaks and to confirm the apoptotic effects caused by single or combined Pcy with $\mathrm{CH}-11$ (Figure 2B). The strand breaks were detected by flow cytometry with the TdT-reaction in the presence of dUTP-FITC. As a positive control, hydrogen peroxide $\left(\mathrm{H}_{2} \mathrm{O}_{2}\right)$ treated cells were included as described in the Materials and methods section. Cells with DNA strand breaks were detected in both cell lines after treatment with single or combined Pcy with $\mathrm{CH}-11$. The Fas receptor agonist (CH-11), when used as a single drug, caused DNA damage in SW480 cells but not in the metastatic SW620 cells.

During Fas-mediated apoptosis, two different signaling pathways have been identified depending on cancer cell type ${ }^{7}$. One of them, is the mitochondrial pathway induced after binding of FasL to its receptor, resulting in the cleavage of Bid protein, the loss of mitochondrial membrane potential $(\Delta \Psi \mathrm{m})$, favoring the release of cytochrome $\mathrm{c}$ and the activation of caspases-9, and -3. We examined whether Pcy and/or $\mathrm{CH}-11$ had an effect on mitochondrial membrane using flow cytometry after staining cells with $\mathrm{DiOC}_{2}(3)$, using CCCP as a positive control as described in the Materials and methods section. $\mathrm{DiOC}_{2}(3)$ accumulates in the mitochondrial matrix and is released in the cytosol after membrane depolarization (membrane with reduced $\Delta \Psi \mathrm{m}$ corresponding to a reduced green fluorescence $)^{4}$. As shown in Figure 2C, the percentage of SW480 cells with depolarized mitochondrial membrane induced by Pcy single $(21 \%)$ or $\mathrm{CH}-11$ $(21 \%)$ was significantly $(\mathrm{p}<0.05)$ increased when Pcy was combined with $\mathrm{CH}-11$ (35\%). Conversely, in
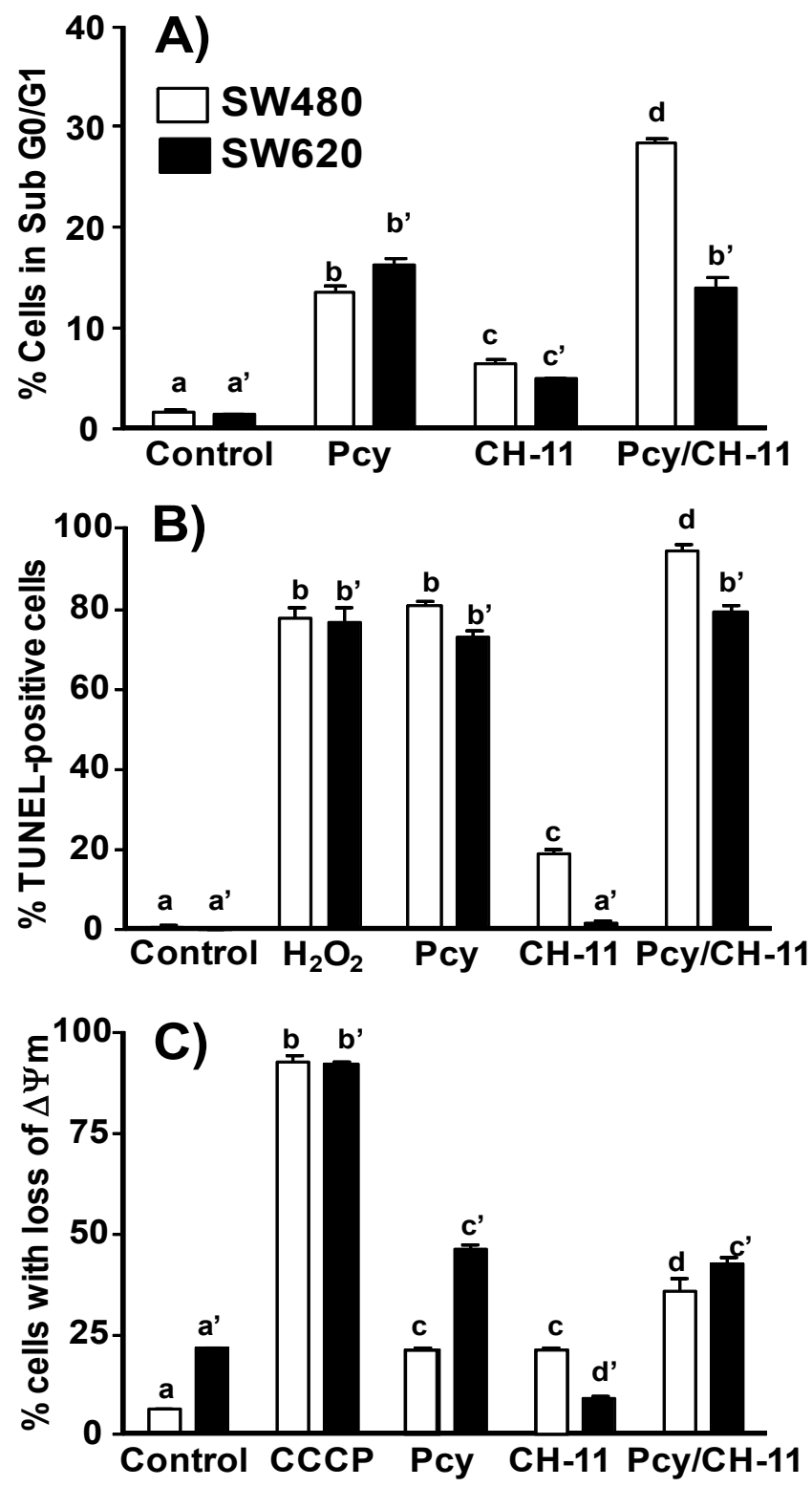

Figure 2. Induction of cell death and $\Delta \Psi$ m reduction of Pcy-treated SW480 and SW620 cells. Treatments were performed with Pcy and/or agonist anti-Fas $\mathrm{CH}-11$ for $48 \mathrm{~h}$. Percentages of hypodiploid cells (subG0/G1 region) (A), apoptotic cells (B), and with reduced $\triangle \Psi \mathrm{m}(\mathrm{C})$ were determined by flow cytometry using $\mathrm{PI}$, TUNEL and $\mathrm{DiOC}_{2}(3)$, respectively, as described in the Materials and methods. Columns represent the mean percentage \pm SE of cells of at least three independent experiments. Statistical differences between groups of treatments were determined by Tukey's multiple comparison posttest. For each cell line, columns not sharing the same superscript letter differ significantly, $p<0.05$. 

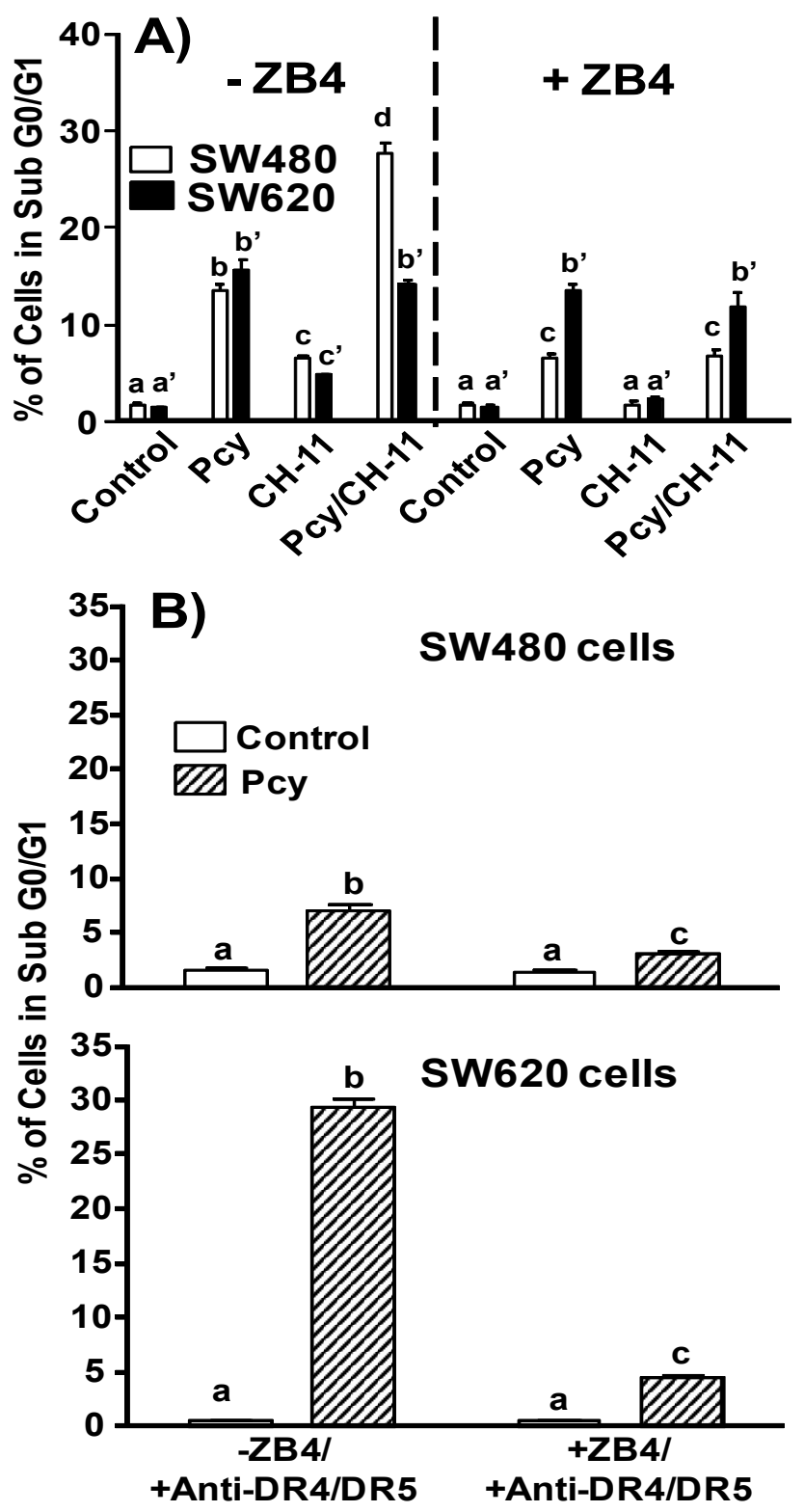

Figure 3. Effect on Pcy-induced cell death after blocking Fas and TRAIL death receptors of SW480 and SW620 cells. Pre-treatments of cells were performed with blocking anti-Fas ZB4 (A) or combined with Anti-DR4/-DR5 (B) followed of Pcy and/or agonist anti-Fas $\mathrm{CH}-11$ treatments for $48 \mathrm{~h}$ to measure the percentage of hypodiploid cells with PI by flow cytometry, as described in the Materials and methods. For each cell line, columns represent mean $\pm S E$ of at least three independent experiments. Tukey's multiple comparison post-test was used to determine statistical differences between groups of treatments, columns not sharing the same superscript differ significantly $(p<0.05)$.
SW620 cells Pcy induced an increased percentage of cells with loss of $\Delta \Psi \mathrm{m}(46 \%)$; however, this effect was not modified after the combined treatment with $\mathrm{CH}-11$ (43\%). Taken together, these results indicate that Pcy enhanced the response of SW480 cells to Fas-mediated apoptosis; whereas, in SW620 cells Pcy did not overcome the cell resistance to $\mathrm{CH}-11$.

Effects of Fas receptor-blocking ZB4 antibody. To investigate the correlation between Fas receptor expression and apoptosis, cells were pre-treated with blocking anti-Fas ZB4 for $1 \mathrm{~h}$ before DMSO (control), Pcy and/or agonist anti-Fas CH-11 treatments for $48 \mathrm{~h}$. In SW480 cells, the blocking Fas receptor caused a significant $(p<0.05)$ reduction in the amount of apoptotic cells (percentage of hypodiloid cells) after $48 \mathrm{~h}$ of treatment with Pcy (from 14\% to 6\%) and Pcy/CH-11 (from $28 \%$ to $7 \%$ ). On the contrary, in SW620 cells, the amount of apoptotic cells was not modified by the blocking antibody (Figure 3A). These data indicate that in SW480 cells, Pcy-triggered death may occur via an activation of the Fas receptor, but this effect was not observed for SW620 cells.

Activation of Fas apoptotic pathway after blocking TRAIL death receptors. In SW480 cells, we showed previously that Pcy-enhanced cell sensitivity to TRAILinduced apoptosis was associated to an up-regulated expression of DR4/DR5 receptors ${ }^{5}$. These findings led us to hypothesize that Pcy might simultaneously activate TRAIL-DR4/DR5 and Fas receptor-mediated apoptosis. Fas- and TRAIL-death receptors were blocked simultaneously with specific blocking anti-Fas (ZB-4) and anti-DR4/-DR5 antibodies before DMSO (control), Pcy and/or agonist anti-Fas CH-11 treatments for $48 \mathrm{~h}$. As shown in Figure 3B, the specific inactivation of DR4/DR5 receptors caused a 50\% reduction in the amount of hypodiploid cells, as observed after Pcy treatment (Figures 2A and 3A). When SW480 cells were exposed to the combination of blocking antibodies, a further significant reduction $(\mathrm{p}<0.01)$ in the percentage of apoptotic cells was observed.

In Pcy-treated SW620 cells, we reported previously that the amount of apoptotic cells was significantly enhanced after blocking TRAIL-death receptors DR4 and DR $5^{5}$. These receptors, as well as Fas are similar in that FADD is recruited directly for activation of the apoptotic cascade ${ }^{9}$. Thus, these results led us to consider that an alternative apoptotic pathway triggered by Pcy 
in SW620 cells after the blocking the TRAIL pathway might involve the activation of the Fas receptor-pathway. To test this hypothesis, we exposed Pcy-treated SW620 cells to blocking antibodies against Fas (ZB4) and DR4/DR5. As shown in Figure 3B, ZB4 counteracted the pro-apototic effects observed after the inactivation of DR4/DR5 receptors reducing by $80 \%$ the amount of apoptotic cells. These data showed that in SW620 cells, Pcy was able to activate the Fas-receptor after blocking TRAIL-death receptors, explaining, therefore, the enhanced apoptosis observed when SW620 cells were exposed to the DR4/DR5 blocking antibody.

\section{DISCUSSION}

We investigated the involvement of the Fas receptor pathway in the Pcy-induced apoptotic response of human colon adenocarcinoma SW480 cells and their derived metastatic SW620 cells. In the present report, we showed that these cell lines responded differently to Pcy-induced apoptosis. Pcy caused a post-transcriptional activation of Fas receptor-mediated apoptosis in SW480 cells. In contrast, the metastatic SW620 cells exhibited a Fasresistant phenotype, as described previously ${ }^{7,14}$ that could not be circumvented by Pcy treatment despite the up-regulation of the Fas receptor gene expression. Surprisingly, activation of the Fas receptor-mediated apoptotic pathway by Pcy was observed in SW620 cells only after blocking TRAIL-DR4/DR5 receptor functions. This result suggests that the Fas-resistant phenotype may be associated to alterations in the downstream events between DR4/DR5 and Fas receptors, a subject that deserves further investigation.

We observed that untreated SW480 cells expressed Fas receptor at a higher level than for SW620 cells in which the expression of the Fas receptor was only marginal, agreeing with previous reports ${ }^{8,14}$. In metastatic SW620 cells, Pcy caused the up-regulation of Fas gene transcripts concomitantly with a huge expression of the receptor at the cell surface. In SW480 cells, Pcy up-regulated Fas receptor expression at a post-transcriptional level with an increased $(>10 \%)$ percentage of cells expressing the receptor at their surface. This suggests that Pcy may favor the delivery of the Fas receptor to the cell membrane. The Fas receptor is a glycoprotein that requires $\mathrm{N}$-glycan posttranscriptional modifications for efficient expression at the cell membrane surface and sensitivity to FasLsignaling, which has been confirmed by inhibiting glycosyltranferases leading to an intracellular accumulation of Fas receptors ${ }^{16}$. Thus, it would be of interest to determine whether Fas glycosilation is involved in the Pcy up-regulated expression of the Fas-receptor at the cellular surface.

The apoptotic signaling pathway activated by the Fas receptor leading ultimately to caspase-3 activation is mediated through two main pathways: the DISC/ caspase-8, and the mitochondria/cytochrome C/Apaf$1 /$ caspase- 9 pathways. The activation of the effector caspase-3, results in the extensive degradation of chromosomal DNA into oligomers of about $180 \mathrm{bp}$. Mitochondria play an important role in cell death signaling ${ }^{18}$, alterations in mitochondrial structure and function occuring in early stages of apoptosis. Further investigations on the Fas receptor function in SW480 and SW620 cells were assessed by combining Pcy with the agonist anti-Fas $\mathrm{CH}-11$ reproducing activation by FasL. Under these conditions, enhanced apoptosis of SW480 cells was observed as evidenced by increased amount of hypodiploid cells, loss of mitochondrial membrane potential, and increased DNA fragmentation. Our data showed that in SW480 cells, the Fas receptormediated apoptotic pathway is activated by Pcy. The mitochondrial alterations observed in these cells by Pcy $+\mathrm{CH}-11$ have also been reported for anti-Fas $\mathrm{CH}-11$ in other experimental models ${ }^{17}$; contrary to the use of multimeric forms of FasL that induce physiologically relevant apoptotic signaling type I (without mitochondria) pathway through the activation of the Fas receptor ${ }^{18}$. The activated type II (mitochondrial) apoptotic pathway by $\mathrm{Pcy}+\mathrm{CH}-11$ may occur simultaneously with an activation of TRAIL-DR4/DR5mediated apoptosis 5 . Simultaneous activation of TRAILdeath- and Fas-receptor mediated apoptosis in colon cancer cells may be considered an important strategy for colon cancer chemoprevention. Indeed, Fas receptor-mediated apoptosis in cancer cells might contribute to the cytotoxic effect of $\mathrm{CD} 8^{+} \mathrm{T}$ and natural Killer (NK) cells infiltrated into the tumor through FasL secreted from $\mathrm{CD} 8+\mathrm{T}$ and $\mathrm{NK}$ cells leading to the elimination of the cancer cells ${ }^{8}$. These results raise the possibility that a combined treatment with Pcy and cytotoxic drugs up-regulating Fas receptor at the cell surface might restore colon cancer cell Fas-sensitivity, 
and may be a promising approach against tumor growth.

On the other hand, SW620 cells were resistant to Fas-receptor mediated apoptosis when treated by Pcy in presence of Fas receptor agonist (CH-11), which did not enhance the apoptotic response of Pcy-treated SW620 cells despite the up-regulated expression of the Fas receptor. The existence of consensus sequences in the promoter of the $F A S$ gene for the $\mathrm{p} 53^{14}$ and NF-kB ${ }^{19}$ transcription factors led us to hypothesize that $\mathrm{p} 53$ and NF-kB might be involved in the increased expression of Fas mRNA transcripts by Pcy in SW620 cells. Further investigations now in progress are necessary to address these questions. Although Pcy did not overcome the Fas-resistance of SW620 cells, Pcy may activate alternative apoptotic pathways. We have previously shown that Pcy initiated in SW620 cells a cross-talk between the TRAIL (extrinsic) apoptotic pathway and the mitochondrial (intrinsic) apoptotic pathway involving enhanced expression of TRAIL-DR4/DR5 receptors in SW480 and SW620 cells, and activated the polyamine catabolismleading to ROS production, which participated in mitochondria disruption ${ }^{4,5}$.

In the present study, we observed that the simultaneous inactivation of Fas and TRAIL-DR4/-DR5 receptors inhibited Pcy-induced apoptosis in SW620 cells; this suggested that Fas resistance in the presence of Pcy may occur at two levels:

i. The ratio between DR4/DR5 and Fas receptors in cell membrane may play a role in determining Fassensitivity. The number of Fas receptors relative to DR4/DR5 might not be sufficient to induce Fasmediated apoptosis, since both types of receptors interact similarly with the FADD adaptor protein ${ }^{20}$ after their activation by the combined Pcy /TRAIL or Pcy/anti-Fas CH-11 treatments;

ii. DR4/DR5 and Fas receptors have different C-terminal tails. The corresponding region for DR4 and DR5 positively regulates FADD binding, caspase activation, and apoptosis; whereas, the C-terminal tail of Fas receptor has the opposite effect and inhibits binding of FADD to the receptor death domain. We may hypothesize that the C-terminal tail of DR4 and DR5 receptors located outside the death domain could represent additional regulatory sites for the activation of the Fas receptor to overcome an inactivation of DR4/DR5 receptors ${ }^{20}$. However, at present there is no evidence showing such a direct interaction between Fas and DR4/DR5 receptors.

In the present report, we demonstrate the ability of Pcy to activate the Fas receptor-mediated apoptotic pathway in the SW480 cells modulating at posttranscriptional level the expression of Fas through a mechanism yet unknown leading to mitochondrial perturbation and DNA fragmentation; whereas, TRAILDR4/-DR5 death-receptor-mediated apoptosis was triggered by Pcy independent of Fas-receptor activation (Figure 4A). This supports the view that Pcy may help cancer cells to recover Fas sensitivity during colon carcinogenesis contributing to the elimination of cancer cells by FasL liberated from im-mune cells. In contrast, the inability of Pcy to sensitize SW620 cells to Fasmediated apoptosis despite Pcy-triggered up-regulation of the Fas receptor expression modulated by Pcy from cell membrane (Figure 4) suggested a loss of function for the Fas that may play an important role in progression toward malignancy. Indeed, it was shown that tumour cells showing resistance to chemotherapeutic agents may concomitantly exhibit resistance to functional Fas receptor expression ${ }^{9,10}$. Our data suggested that in Fasresistant SW620 cells, Pcy were able to initiate a crosstalk between death receptors because specific blocking of TRAIL death receptors favored activation of the Fas receptor-mediated apoptosis (Figure 4B). These important data may allow the emergence of new therapeutic protocols targeting death receptors in metastatic cells. Further investigations have to be extended to other cancer cells to understand and identify the mechanisms by which Pcy might be able to increase cell sensitivity and bypass resistance to Fas-induced apoptosis.

Conflict of interest. None of the authors has conflicts of interest related to this study.

\section{ACKNOWLEDGEMENTS}

This research was supported by the Ligue Francaise Contre le Cancer, by the European Development Regional Fund (FEDER) from Strasbourg, France and by the Francisco José Caldas Institute for the Development of Science and Technology (COLCIENCIAS), Bogotá, Colombia. 

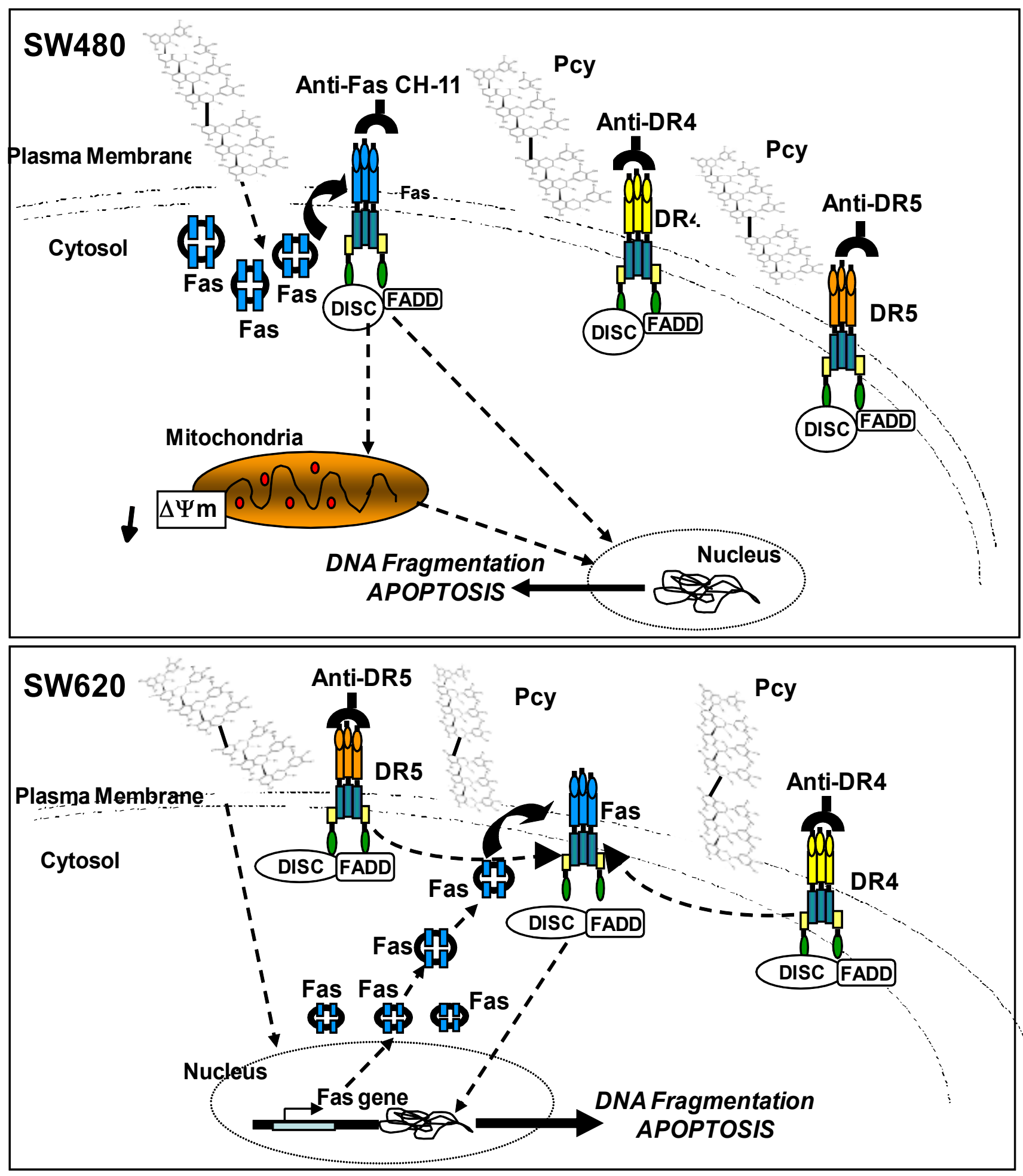

Figure 4. Scheme of the Fas-receptor mediated apoptotic pathways activated by Pcy in SW480 (A) and SW620 (B) cells 


\section{REFERENCES}

1. Van Breda SG, de Kok TM, van Delft JH. Mechanisms of colorectal and lung cancer prevention by vegetables: a genomic approach. J Nutr Biochem. 2008; 19: 139-57.

2. Gerhauser C. Cancer chemopreventive potential of apples, apple juice, and apple components. Planta Med. 2008; 74: 1608-24.

3. Gossé F, Guyot S, Roussi S, Lobstein A, Fischer B, Seiler N, et al. Chemopreventive properties of apple procyanidins on human colon cancer-derived metastatic SW620 cells and in a rat model of colon carcinogenesis. Carcinogenesis. 2005; 26: 1291-5.

4. Maldonado-Celis ME, Roussi S, Foltzer-Jourdainne C, Gossé F, Lobstein A, Habold C, et al. Modulation by polyamines of apoptotic pathways triggered by procyanidins in human metastatic SW620 cells. Cell Mol Life Sci. 2008; 65: 1425-34.

5. Maldonado-Celis M, Bousserouel S, Gossé F, Minker C, Lobstein A, Raul F. Differential induction of apoptosis by apple procyanidins in TRAIL-sensitive human colon tumor cells and derived TRAIL-resistant metastatic cells. J Cancer Mol. 2009; 5: 21-30.

6. Strasser A, Jost PJ, Nagata S. The many roles of FAS receptor signaling in the immune system. Immunity 2009; 30: 180-92.

7. Bergmann-Leitner ES, Abrams SI. Differential role of Fas/Fas ligand interactions in cytolysis of primary and metastatic colon carcinoma cell lines by human antigen-specific CD8+ CTL. J Immunol. 2000; 164: 4941-54.

8. O'Connell J, Bennett MW, Nally K, Houston A, O'Sullivan GC, Shanahan F. Altered mechanisms of apoptosis in colon cancer: Fas resistance and counterattack in the tumor-immune conflict. Ann NY Acad Sci. 2000; 910: 178-92.

9. Bhushan A, Kupperman JL, Stone JE, Kimberly PJ, Calman NS, Hacker MP, et al. Drug resistance results in alterations in expression of immune recognition molecules and failure to express Fas (CD95). Immunol Cell Biol. 1998; 76: 350-6.

10. Souquet JM, Labarbe B, Le Guerneve C, Cheynier V, Moutounet M. Phenolic composition of grape stems. J Agric Food Chem. 2000; 48: 1076-80.
11. Livak KJ, Schmittgen TD. Analysis of relative gene expression data using real-time quantitative PCR and the 2(-Delta Delta C(T)) method. Methods. 2001; 25: 402-8.

12. Nicoletti I, Migliorati G, Pagliacci MC, Grignani F, Riccardi C. A rapid and simple method for measuring thymocyte apoptosis by propidium iodide staining and flow cytometry. $J$ Immunol Methods. 1991; 139: 271-9.

13. Gavrieli Y, Sherman Y, Ben-Sasson SA. Identification of programmed cell death in situ via specific labeling of nuclear DNA fragmentation. J Cell Biol. 1992; 119: 493-501.

14. Huerta S, Heinzerling JH, Anguiano-Hernández YM, HuertaYepez S, Lin J, Chen D, et al. Modification of gene products involved in resistance to apoptosis in metastatic colon cancer cells: roles of Fas, Apaf-1, NFkB, IAPs, Smac/DIABLO, and AIF. J Surg Res. 2007; 142: 184-94.

15. Li Y, Yang X, Nguyen AH, Brockhausen I. Requirement of $\mathrm{N}$-glycosylation for the secretion of recombinant extracellular domain of human Fas in HeLa cells. Int $J$ Biochem Cell Biol. 2007; 39: 1625-36.

16. Russo M, Nigro P, Rosiello R, D’Arienzo R, Russo GL. Quercetin enhances CD95- and TRAIL-induced apoptosis in leukemia cell lines. Leukemia. 2007; 21: 1130-3.

17. Huang DC, Tschopp J, Strasser A. Bcl-2 does not inhibit cell death induced by the physiological Fas ligand: implications for the existence of type I and type II cells. Cell Death Differ. 2000; 7: 754-5.

18. Clemons NJ, BuzzardK, SteelR, Anderson RL. Hsp72 inhibits Fas-mediated apoptosis upstream of the mitochondria in type II cells. J Biol Chem. 2005; 280: 9005-12.

19. Henson ES, Gibson EM, Villanueva J, Bristow NA, Haney N, Gibson SB. Increased expression of Mcl-1 is responsible for the blockage of TRAIL-induced apoptosis mediated by EGF/ ErbB1 signaling pathway. JCell Biochem. 2003; 89: 1177-92.

20. Thomas LR, Johnson RL, Reed JC, Thorburn A. The Cterminal tails of tumor necrosis factor-related apoptosisinducing ligand (TRAIL) and Fas receptors have opposing functions in Fas-associated death domain (FADD) recruitment and can regulate agonist-specific mechanism of receptor activation. J Biol Chem. 2004; 279: 52479-86. 